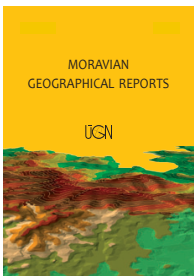

MORAVIAN GEOGRAPHICAL REPORTS

\title{
Mapping urban agriculture in Portugal: Lessons from practice and their relevance for European post-crisis contexts
}

\author{
Cecília DELGADO * *
}

\begin{abstract}
A significant sample of twenty-nine Portuguese urban agriculture (UA) initiatives is analysed in this article. It argues that emerging initiatives are relevant for shifting from a post-crisis approach to one that is more developmental. This multi-level analysis finds that UA in Portugal: embraces allotment gardens, urban farms and short food chains; deals primarily with vegetables and fruit; takes place predominantly on public and institutional land; and is championed by municipalities and to a lesser extent by civil society initiatives. UA is predominantly a metropolitan phenomenon. Furthermore, activities are organised around three pillars: production of food; simple processing and distribution; and a significant set of capacity building and training activities. UA is recent phenomena in Portugal, and it has expanded quickly since the 2008 economic crisis. The paper explores in-depth four innovative short food chains from the sample of initiatives. They are led by young entrepreneurs, make positive use of social networks, are committed to social and economic values, and expanded successfully in generating jobs at the time of the crisis. These examples strongly suggest that UA social economy enterprises are a driving force behind integrated sustainable development approaches in European cities, if and when supported by public policies.
\end{abstract}

Key words: urban agriculture; short food chains; post-crisis Europe; Portugal

Article history: Received 24 January 2017; Accepted 23 June 2017; Published 30 September 2017

\section{Introduction}

Debates over the relationships between Urban Agriculture (UA) and cities have increased over the past two decades. Cruz and Aguila (2000) defined this relationship in terms of economic value and the circulation of resources and products, emphasising the role of small-scale production on empty and abandoned plots through their integration into the local agricultural chains. Several years later, Mougeot (2015) proposed various levels of integration of urban agriculture into the urban economy and ecology based on four strategies: (1) the land rent of urban agriculture production; (2) the value chains of urban agriculture; (3) the multiple functions of urban agriculture production sites: and (4) the physical connectivity of urban agriculture production sites by improving resource utilisation.

In spite of the passionate and extensive debate among academics and some practitioners, Urban Agriculture has been neglected for decades by both urban and agricultural policy makers - as urban planners treated agricultural land as potential building ground and agricultural policies focused on rural areas (Lohrberg, 2016). Portugal is no exception. For long time food has been forgotten in city planning (American Planning Association, 2007), and far from urban agendas (Pothukuchi and Kaufman, 1999). Nevertheless, integration of food into urban planning is an emerging topic (Morgan, 2014) all over the world in spite of it still being underappreciated (Cabannes and Marocchino, 2016).

Being a broader issue and interdisciplinary field, UA requires a clear scope. From an urban planner's perspective, UA might be considered as a driver to:

1. propose alternatives to existing land use plans and vacant plots;

2. legitimise existing occupations through integration into the local agricultural chain;

3. provide municipalities with sustainable and long-term local development solutions, based on the economic and social empowerment of communities;

4. generate jobs and increase income; and

5. strengthen multi-level governance and deepen citizen participation mechanisms through collaborative processes.

Remarkably, conventional definitions and prevailing international approaches to UA are slowly being called into question in Southern European countries such as Portugal, due to emerging and innovative UA initiatives (Wascher

\footnotetext{
${ }^{a}$ Interdisciplinary Centre of Social Sciences, Faculty of Social Sciences and Humanities, Nova University of Lisbon, Portugal (*corresponding author: e-mail: cmndelgado@gmail.com)
} 
et al., 2015). Existing definitions are vague, however, and UA remains a confused and broad topic. In Section 3, selected UA definitions will be presented in order to discuss the limits to framing a UA State of the Art. The first contribution of the present paper is precisely to propose a conceptual framework for engaging critically with UA, supported by the following research question: To what extent do current definitions of UA reflect and value emerging and innovative UA initiatives, beyond a vision of UA for subsistence and poverty mitigation? Our assumption is that prevailing conceptions of UA need some adjustments in order to reflect local social and economic innovations.

Since J. Innes (Innes and Booher, 1999; Innes and Booher, 2010) and P. Healey (Healey, 2004; Healey, 2006) proposed collaborative planning theory in the 1990s as a new planning-development paradigm that, in a nutshell, considers policy planning as a social process, i.e. involving actors from the local population as well as technicians and decision makers, among others, in a systematic approach, many practitioners have found their ideas too abstract and difficult to relate to their concerns (Goodspeed, 2016). One problematic issue is that the theory does not sufficiently reconcile local agreements with external perspectives or account adequately for issues of power (Huxley and Yiftachel, 2000, Fainstein, 2000). This is particularly relevant in Southern European countries, such as Spain, Portugal and Italy, where governments recognise the significance of new democratic approaches even if citizen participation is seldom achieved in practice (Schaap et al., 2009).

The second contribution of this paper is to an ongoing theoretical debate, framed by the following research question: To what extent is collaborative planning theory adequate for understanding and facilitating the development of UA programmes. The current integration of UA in Portuguese cities is fragile, as will be discussed further. A related theoretical question is framed as follows: Can collaborative planning theory help bridge the gaps between diverse and unbalanced stakeholders in the processes and support long-term transformative change? This topic is critical, as the development of cities cannot be achieved without governments working with communities (Rauscher and Momtaz, 2015). This paper advocates for a collaborative planning theory approach as a way to develop a common vision on UA integration at the city-wide scale, even though our experience in working with Portuguese municipalities and local associations shows how limited is the level of mutual understanding.

In order to develop and scale up UA in Portugal, a State of the Art formulation is necessary, including mapping out existing and disappearing initiatives. This paper maps out and analyses a significant sample of Portuguese UA initiatives, based on a set of 29 cases selected by key stakeholders from national associations, academia, municipalities, local champions, and gardeners with a long involvement in food issues. Multi-level perspective theory (Geels, 2011) helps to explain what is currently happening in Portugal. On the one hand, the 'regime', which refers to the dominant mind-set of UA practice, promotes large projects of allotment gardens, but on the other hand there are young social entrepreneurs using innovative means to address societal challenges, including mass unemployment and the failure of the welfare state.

At this point we arrive at the third and final research question of this paper: How can crisis-induced initiatives represent an opportunity to integrate UA with the city in the long-term? Our central argument is that UA in Portugal is a burgeoning field that has been rapidly expanding as a result of the effects of the 2008 socio-economic crisis. In addition to a consistent number of allotment gardens promoted by some institutions and municipalities, a significant number of extremely creative initiatives that share in common values with the social and solidarity economy, are consolidating, showing that UA is an important opportunity. Our theory, based on the lessons learned from the mapping of the UA Portuguese initiatives, is that the UA innovative short food chains can be drivers for sustainable urban development and the integration of UA with the city (Mougeot, 2005, Mougeot, 2015).

The rise of initiatives concerning food and UA, which have started to spread across various Portuguese cities, calls for a place for UA on the national agenda. This reflects a tremendous need and presents a unique opportunity to deepen the debate, and to develop broader understandings of the specificities and trends of UA in Portugal as short food chains.

The next section presents an overview of the State of the Art of Portuguese UA in the context of the economic crisis and the solidarity economy, based on a literature review, as well as a brief explanation of Portugal's historical development in relation to other European countries. Section 3 illustrates how the methodology for this research was developed and the data selected. An in-depth discussion is based on 29 initiatives selected by a relevant set of key informants (Section 4). Out of this target universe, four cases of short food chains are surveyed in detail, as they represent an alternative to the conventional mainstream allotments initiatives. More importantly, when taken in their diversity they are particularly interesting in bringing primary answers to the three research questions introduced previously. Finally, in Sections 5 and 6 we discuss the findings and their contribution to the theoretical and conceptual debates, including the previous research questions.

\section{Theoretical background: Urban agriculture in Portugal from gardening to socio-economic development}

This paper is part of a larger research and development project on the role of UA and Urban Planning Policies in Portugal as drivers of city development that began at the end of 2014. Briefly, the process so far has included the following elements: a scoping study on urban agriculture and the refinement of research questions; the design of research instruments; identification and selection of empirical cases; case study visits; interviews with relevant actors and key informants; data processing and analysis; dissemination of results in scientific journals; and feedback to engage actors locally, nationally and internationally.

The economic crisis that struck Portugal in 2008 brought about a significant increase in allotment gardens (Delgado, 2015). According to the Portuguese national report to Habitat III (Branco, 2016) in 2013, 16 out of a total of 18 districts have allotment garden initiatives, which together constitute 27 hectares of hortas urbanas. The crisis also spurred a huge campaign launched by the Portuguese State emphasising the potential of social entrepreneurs (Casaqui, 2015). Existing data from the National Statistics Institute (INE-CASES, 2013) show an increase of the number of social organisations in Portugal dealing with food, such as the Fruta Feia (Ugly Food) Cooperative that will be analysed 
further below. In 2010 the number of social organisations for all sectors amounted to 55,000, and increased to 61,000 in 2013. Paid jobs generated in this sector increased from $5.5 \%$ in 2010 to $6.0 \%$ in 2013 , which illustrates the development of the Portuguese social economy.

The first formal Portuguese allotment garden opened in 2003, before the crisis, led by LIPOR (Lipor, 2017), a municipal waste management enterprise based in Porto Metropolitan Area that is active in eight municipalities today. One year later, Coimbra Municipality and its University together transformed an informal community garden close to a low-income neighbourhood into a formal, regulated space. Also Funchal Municipality (CMF, 2015) on Madeira island, started a formal programme of allotment gardens in 2005 , which is active today in 23 city spaces, with the majority created after the 2008 crisis and involving more than 900 families. This national process culminated in the first and only national and international conference on UA organised by Seixal Municipality in 2011 (Lança, 2011), which brought together 250 researchers and practitioners. The conference took place in the context of high levels of unemployment (Pascual, 2015) and pressure from low income groups searching for means of producing food (Luiz and Jorge, 2011, Cabannes and Raposo, 2013, Delgado, 2015).

In 2011, Lisbon Municipality began an ambitious programme called "Parques Horticolas Municipais" (CML, 2016) which today comprises 25 urban spaces, involving more than 500 families. Information is not currently available to assess how many farmers are practising UA with or without formal status. A continuous practice of smallscale subsistence agriculture remains in place in Portugal, however, primarily in rural and peri-urban areas.

A review of the literature on Portuguese Urban Agriculture mainly draws on $\mathrm{PhD}$ and Masters theses, bringing some light to several squatter gardens, such as Horta do Monte in Lisbon and Quinta das Musas in Porto (Santos, 2011), Vale de Carnide in Lisbon (Cardoso, 2012) and Oeiras, on the outskirts of Lisbon (Saraiva, 2011). There also exists literature on allotment gardens in Lisbon (Ramos, 2011, Gonçalves, 2014, Cancela, 2014), and some specific cases on the Lisbon outskirts such as Cascais (Abreu, 2012) and Seixal (Rodrigues, 2012) to name a few. Even with a limited number of cases, this allows us to precisely understand that Portuguese UA is focused on food production for self-consumption among informal or formal frameworks, and is mainly located in the metropolitan areas of Lisbon and Porto. So far, a key lesson is the absence of UA from a city food system approach that connects producers, distributors, processors, retailers, formal and informal markets, restaurants, institutional food services and waste management (Raja et al., 2016).

\subsection{Portugal in an historical European context}

In northern European countries, UA has been shaped by industrialisation (Crouch and Ward, 2007), as well as the wars and crises in the $20^{\text {th }}$ century (Bryant et al., 2016). After the First World War, countries such as Britain and Germany developed specific allotment gardens programmes as a response to food crises. Portugal's relatively late industrialisation, as well its absence from the Second World War, help to explain why formal allotment gardens were not part of municipal policy in the last century.

Another European process occurred roughly ten years after the First World War, in 1926 when several countries established the Federation of Allotment Gardens in
Luxembourg, an organisation that today comprises over 3 million people from 14 countries (Coin de Terre et des Jardins Familiaux, 2014). Portugal and other Southern European countries, however, are not part of it.

At the beginning of the twentieth century, Portugal was predominantly a rural society and the primary sector employed $60 \%$ of the work force (Ferraz, 1975). The country was marked by a late industrialisation process, mainly concentrated around Lisbon and Porto (Teixeira, 1993). In addition, Portugal's dictatorial period from 1933 until 1974 explains the slow process of urbanisation that only began to accelerate in the $1980 \mathrm{~s}$, driven by Portugal's entry to the European Union in 1986. This marks the start of the societal changes and new patterns of consumption in cities that constitute the frame for UA expansion described in this paper.

With the beginning of massive urban development through the 1980s, Portugal turned its back on agriculture. Unsurprisingly, since the integration of Portugal into the European Union, urban agriculture was neither a key issue in debates nor a supported sector. This means that today Portugal has an unbalanced food system, needing to import food to supply it owns needs (FAO, 2017).

\subsection{Portugal slowly returning to agriculture}

A turning point happened during the 2000 s, when local food systems and urban agriculture in Portugal began to benefit from European Programmes such as Leader+, which ran between 2000 and 2006 and supported the PROVE programme (2006). PROVE is a national, emblematic short food chains enterprise-oriented initiative, connecting producers directly with consumers (PROVE, 2017), and it will be referred to further below. European research programmes such as Cost Urban Allotments Garden in European Cities (2012-2016), and Cost Urban Agriculture Europe (2012-2016), which integrated Portuguese teams and initiatives, played a significant role in connecting Portuguese UA initiatives and debates with those taking place in other European countries (Bell et al., 2016, Lohrberg et al., 2016). Still, the process takes time and needs a lot of UA advocacy. Such processes are being conduced by the Portuguese non-governmental organisation, OIKOS, on the Milan Urban Food Policy Pact (OIKOS, 2017). This international protocol aims to engage cities around the world, particularly Mayors, for the development of just and sustainable urban food systems (MUFPP, 2015). In approximately one year, 137 member cities from over the world, including several European cities, joined the Pact; so far none of them are Portuguese. Nevertheless, 30 cities showed interest in a public event organised at the beginning of 2016 by OIKOS.

\subsection{Urban agriculture integration into the urban economy}

It is not possible to understand how Portuguese UA is integrated into the urban economy in terms of distribution and consumption, given the lack of national data. Members of the social or solidarity economy sector, however, including consumers cooperatives such as Fruta Feia (Fruta Feia CRL, 2017) and ADREPES, a non-governmental organisation that leads the PROVE programme, are emphasising the need to have a closer look at this sector.

The concept of social economy and social entrepreneurship is relatively new. Its origins can be recorded in the 1980s in the USA, and its arrival in Portugal happened in the first decade of the $21^{\text {st }}$ century (Quintăo and Parente, 2015), 
with the first social economy law appearing in early 2013 (Law No. 30/2013). Interestingly, the topic emerged in 2011 when Portugal was hit by a dramatic economic crisis and lack of liquidities, which led to the signature of an MOU (Memorandum of Understanding) with the socalled "Troika" composed of the International Monetary Fund (Pascual, 2015), the European Central Bank and the European Parliament. As a consequence, these three institutions took over the economic sovereignty of the nation and spearheaded harsh austerity (economic and social) measures from April 2011 to May 2014 - as a condition to respond to the country's request for external financial aid.

The four short food chains initiatives analysed in this paper are examples of food solutions that came from the economic enterprise sector but others can be given, such as the national programme RE-Food that collects food waste from restaurants and other local food establishments and distributes it to local populations, all through voluntary service, at more than 30 distribution points covering the Portuguese territory. Another example are the openair organic street fairs managed by the national organic association Agrobio that exists in several Portuguese cities. These initiatives were not listed by the group of key informants, which clearly illustrates the need for a conceptual debate on a definition of UA that would include such initiatives.

\section{Methodology and data collection}

The first challenge comes from the lack of a widelyaccepted definition that would help delineate the contours of UA, although some existing international definitions are generally accepted by the scientific community and most stakeholders. Despite variations among definitions, one useful example states: "(UA is) the growing of plants and the raising of animals within and around cities, embedded in - and interacting with - the urban ecosystem. Including the use of urban residents as labourers, use of typical urban resources, direct links with urban consumers, direct impacts on urban ecology, being part of the urban food system, competing for land with other urban functions, being influenced by urban policies and plans." (RUAF, 2006). From the territorial perspective, UA definitions agree that UA is located in urban and peri-urban areas, i.e. not strictly related to the urban core (Mougeot, 2000, Mougeot, 2005, RUAF, 2006, FAO, 2009, Zeeuw and Drechsel, 2015, Lohrberg et al., 2016). Currently, only RUAF's (2006) definition stresses the need for UA to compete for land with other urban functions and being influenced by urban policies and planning, despite the international recognition of its importance.

There is a converging standpoint in terms of UA being part of the urban system, and conducted by and for urban actors. Additionally, some definitions introduce animal raising or aquaponics production (Veenhuizen, 2006), an issue that does not find a consensus between authors. Finally, a new trend can be found in the later Cost publication Urban Agriculture in Europe (Vejre and Simon-Rojo, 2016) concerning biological production-related issues.

This brief presentation of UA's conceptual definitions illustrates the problem: UA is a diffuse entity, i.e. not defined by quantitative dimensions; unstable, i.e. it changes through time; boundless, i.e. different definitions are prioritising diverse topics, e.g. from land planning to animal raising or aquaponic production; plus it is locally specific, e.g. only Cost UA European definition considers organic production as a key issue. In conclusion, UA lacks a conceptual framework, which is itself a methodological challenge concerning making any UA State of the Art assertion.

\subsection{The target universe of urban agriculture in Portugal (29 selected cases)}

In order to substantiate or contribute to the national and international debates and in spite of the limitations presented by definitions of UA, this research project began with the perceptions of twelve key stakeholders, in order to obtain their reflections on UA in Portugal. The stakeholders were selected from four sets of actors: [a] members of institutions and networks with a national coverage; $[\mathrm{b}]$ scholars and academics; [c] workers from the public sector; and [d] members of grassroots and local civil society organisations.

The main aspects of this exploratory phase of the research are as follows:

a. half of the interviewees were representatives of the most prominent and active organisations with national coverage, namely the National Portuguese Network of Urban and Peri-urban Agriculture, the National Association of Landscape Architects, the National Association of Organic Agriculture, the National Association of Horticulture, and the National Champion of the Prove Program;

b. interestingly, the scholar from the Environment Department of Nova University in Lisbon was also a practising urban gardener engaged in local actions;

c. the public sector interviewees came from the Ministry of Agricultural Regional Directorate for Lisbon and the Tejo Region, as well as two representatives from the Lisbon and Sesimbra (Lisbon Metropolitan Region) local governments; and

d. finally, two champions from Lisbon-based local organisations (Horta do Mundo and AVAAL) completed the set.

The interviews were conducted between October and December, 2015. To select key informants a reputational process (snowball) of sampling was used (Atkinson and Flint, 2001; Biernacki and Waldorf, 1981), i.e. each interviewee suggested three new relevant actors, resulting in a stable network of twelve actors. The participants were gender-balanced and ranged from 40 to 60 years old. A semi-structured interview covering several UA dimensions was conducted. In addition, participants were asked to indicate initiatives that they felt were paradigmatic models of UA in Portugal. From the key informants' indications, a consolidated list was created. This list comprised 29 projects and programmes.

The 29 cases from the key informants (see Tab. 1) are only a sample of the universe of UA initiatives in Portugal; in other words, they represent the target population of concern in this project, effectively illustrating this exploratory research in that it is not representative of all the initiatives in progress. Regardless, these cases together constitute a unique empirical collection of significant initiatives to map out a first UA profile for the country, and they are consistent enough to ignite a debate based on such primary information from relevant national UA stakeholders.

The full investigation of the 29 cases was developed by the author between January 2015 and December 2016, using a variety of methods and tools to gather and consolidate the non-systematic data: a) systematic and repeated web site visits; b) site visits; c) in-depth interviews of key informants 
and practitioners and farmers involved; d) occasional exchanges with producers, consumers, supporters and partners; and e) networking activities and participation in seminars on urban agriculture-related events in order to get better insights on initiatives. These different research activities generated a climate of trust with several of the programmes and initiatives, and this opened up the possibility to complement information and verify accuracy when necessary. The boundaries between research and a citizen's involvement in a small country such as Portugal are difficult to establish.

Given the extreme diversity of the projects and initiatives that were part of this composite list, one of the challenges for the research was how to define analytical categories that would be sensitive enough to capture the diversity of situations. At the same time, such an analytical tool should highlights elements that would help sketch out a Portuguese UA profile with some accuracy, grounded in evidence and hard facts.

\subsection{Proposed multi-dimensional analysis}

The heterogeneity of the 29 UA initiatives identified corresponds with the diversity of the key national informants that were invited to establish the reference list. A multidimensional analysis was designed, starting with a long list of dimensions that were tested on the existing cases. The information that was available and the quality of results led to differentiation between two levels: the first level is intended to define a stable platform of dimensions that can easily be used as comparative tools with other country profiles. In order to do this a combination of RUAF and Cost Action UA in Europe key dimensions were used, covering:

1. typology of UA initiatives;

2. territorial scale and locations; and

3. what is being produced and distributed.

The second level is specific and local: an in-depth MultiDimensional Analysis with the aim of generating and understanding Portuguese UA's specificities. It covers five dimensions:

1. land for UA;

2. leadership and partnership;

3. asset mapping;

4. duration; and

5. activity patterns.

This second level was tailored to the very nature of the 29 cases. This was a contribution to the establishment of initiative-based UA profiles in specific locations.

\section{Results: A preliminary national urban agriculture profile}

\subsection{First multi-dimensional level}

\subsubsection{Typology of UA initiatives}

The cases can be organised into the following typology (see Tab. 1): Allotments Gardens; Programmes and Projects; Short Food Chains: Urban Farms; Others.

\section{a. Allotments gardens (15/29)}

According to Simon-Rojo et al. (2016), urban food production encompasses agricultural activities with low economic emphasis on material outputs, while using the production of food for achieving other, mostly social goals. Broadly this is true for the majority of cases in this study. Further analysis will highlight how this category is heterogeneous, however, and deserves to be unpacked.

The leisure allotments that are now part of 25 Lisbon public parks (Ramos, 2011, Gonçalves, 2014) (case 2) and the recently opened AVAAL (case 4), a two-hectare allotment site in a large middle class development (Cancela, 2014), share very little in common with grassroots initiatives close to low-income social housing at the peripheries of cities (cases 11 and 13). Such social housing areas are struck by poverty and social exclusion and cultivating food remains an activity for subsistence. Most of the cases falling into this category are managed by local government authorities, a few by institutions and foundations, and only one can be identified as a community-led initiative (case 13) on nonregularised land (Cabannes and Raposo, 2013).

b. UA programmes and projects (6/29)

These programmes and projects focus mainly on capacity building, training and education rather than production. They are promoted by an interesting array of groups of individuals, institutions, or public bodies that have started to invest resources into UA such as a public bank (case 16), a cultural foundation (case 18), and a municipality (case 20) that promotes business-oriented capacity building.

c. Short food chains $(4 / 29)$

These projects highlight primarily the economic dimension of UA (Lordleberg, 2016) as they refer to commercial food distribution. Four innovative initiatives fall under this category and are of a radically different nature when compared with the others. In the context of Portugal they are at the cutting edge of addressing food issues. They broadly fall under the category of the social and solidarity economy, and promote direct or short distribution circuits between local producers and mostly urban customers. Their originality and potentials, quite in tune with the European evolution of UA, will be examined in depth in section 4.

d. Urban farms (3/29)

Urban farming refers to intentional business models taking advantage of proximity to the city (Simon-Rojo et al., 2016), again emphasising UA's economic dimension. The productive farms all work with vulnerable and excluded groups (inmates, disabled people), and are located in Lisbon and neighbouring cities. They attempt to sell and distribute the products cultivated beyond self-consumption, in order to generate income towards self-sufficiency, as is the case of Cercica (case 28) or Setúbal jail (case 12) (Almeida, 2012).

e. Others $(1 / 29)$

Loja dos Produtos Rurais (case 29) is a gourmet shop located in Lisbon selling products from various regional producers from the region, and currently closed. One key informant mentioned it as one of the references of new trends of UA.

\subsubsection{Territorial scale and location}

The map in Figure 1 gives an overview of the locations of the 29 selected initiatives. They can be organised roughly into three different scales:

a. Very few have reached national or multi-city coverage Programa PROVE (case 22) is an exception as it established short distribution chains between 137 smallscale producers and 7,000 consumers living in the main cities of the country, primarily in the Lisbon and Porto Metropolitan Areas. A second initiative, Fruta Feia 
Allotment Gardens (15)

(1) Horta à Porta - LIPOR, Porto Metropolitan Area

Allotment Garden at your Door

(2) Parques Hortícolas de Lisboa

Lisbon Horticultural Allotment Park

2011

(3) Hortas de Cascais

(4) Horta AVAAL, Lisboa

Cascais Allotments Gardens

(5) Hortas de Guimarăes

(6) Hortas Urbanas de Vila Franca de Xira

Assoc. for Development of Lisbon High Allotment Gardens

Vila Franca de Xira Allotments 2010

(7) Hortas do Centro Hospital Conde Ferreira, Porto

Conde Ferreira Hospital Allotments

(8) Parque Hortícola da Quinta da Várzea, Sesimbra

Horticultura Park Varzea Allotment Gardens

(9) Hortas de S. Joăo, Almada

\section{S. Joăo Allotment Gardens}

(10) Hortas de Vila Nova de Gaia

(11) Horta do Ingote, Coimbra

(12) Hortas do Funchal, Madeira Island

(13) Hortas na Cova da Moura, Amadora

Vila Nova de Gaia Allotmen Gardens

Ingote Allotment Garden

Funchal Allotment Gardens

Cova da Moura Allotment Gardens 2003

(14) Hortas Bairro Boavista, Lisboa

Boavista Neighbourhood Allotment Gardens

(15) Hortas Urbanas da Moita

Moita, Allotment Gardens

Programs and Projects (6)

(16) Horta da Caixa Geral de Depósitos, Lisboa

Bank Foundation

(17) Projeto Horta Integrada, Lisboa

Serralves Foundation Allotment

(18) Hortas da Fundaçăo de Serralves, Porto

From farm to plate Program

(19) Programa da quinta para o prato, Palmela

(20) Hortas Empresariais, Loures

Loures Business Allotment Gardens

(21) Horta do Baldio, Lisboa

Wasteland Allotment Garden

Short Food Chains (4)

(22) PROVE, Portugal

(23) Cabaz do Peixe, Sesimbra

24) Fruta Feia, Lisbon \& Porto Metropolitan Areas

(25) Biovivos, Lisbon, Porto \& Faro

Urban Farms (3)

(26) Projeto Semear, Lisboa

(27) Horta Prisăo de Setúbal

(28) Cercica de Cascais

Others (1)

(29) Loja Produtos Rurais, Lisboa
Taste Program

2006

Fish Basket

2015

Ugly Fruit

2013

Organic Greens

2014

Growing seed Project

Jail Farm

Training Centre for Disable People

Tab. 1: Typology of UA initiatives

Source: author's elaboration based on information from local actors and key-informants (2017)

(case 24), collects fruit and vegetables that are rejected by the corporate sector through a large network of producers that covers a large portion of the territory. However Fruta Feia only distributes the collected food in Lisbon and Porto Metropolitan Areas;

b. While UA in Portugal is dominantly a metropolitan phenomenon, this map clearly indicates the concentration of initiatives taking place partially or exclusively in Lisbon and Porto Metropolitan Regions, the most densely populated areas of the country; 22 out of the 29 in Lisbon and 7 out of 29 in Porto. Lisbon and its region is by far the most active UA region;

c. There exist limited but growing UA activities in secondary cities. On the one hand, PROVE is active in secondary cities from North to South. Interestingly enough other cities such as Coimbra, Guimarăes have developed specific allotment programmes. A special reference needs to be made also to Funchal Municipality, Capital of Madeira Island, for its long-standing and multi-location programme, for the promotion of allotments for selfconsumption; and

d. Smaller towns and villages - No programmes or initiatives that would take place in smaller human settlements were indicated by the key informants. As for the secondary cities, or even metropolitan areas, there are examples of small- or medium-sized initiatives, but these are isolated or simply at an early stage. The topic deserves future attention. 


\subsubsection{What is being produced and distributed}

UA in Portugal deals primarily with traditionally consumed vegetables: green leafs (salads, cabbages, etc.), roots and tubers (potatoes), and tomatoes (Delgado, 2016). To a much lesser extent fruit and flowers are being considered, despite programmes such as Fruta Feia and PROVE that distribute a large variety of fruits produced locally. Some allotments gardens have also introduced orchards with some success.

Healthy micro greens (case 25) have largely expanded and are being distributed in various cities as high quality products. They are a unique example of diversification of UA products towards new market niches. Another original initiative is the distribution of local fish (case 23).

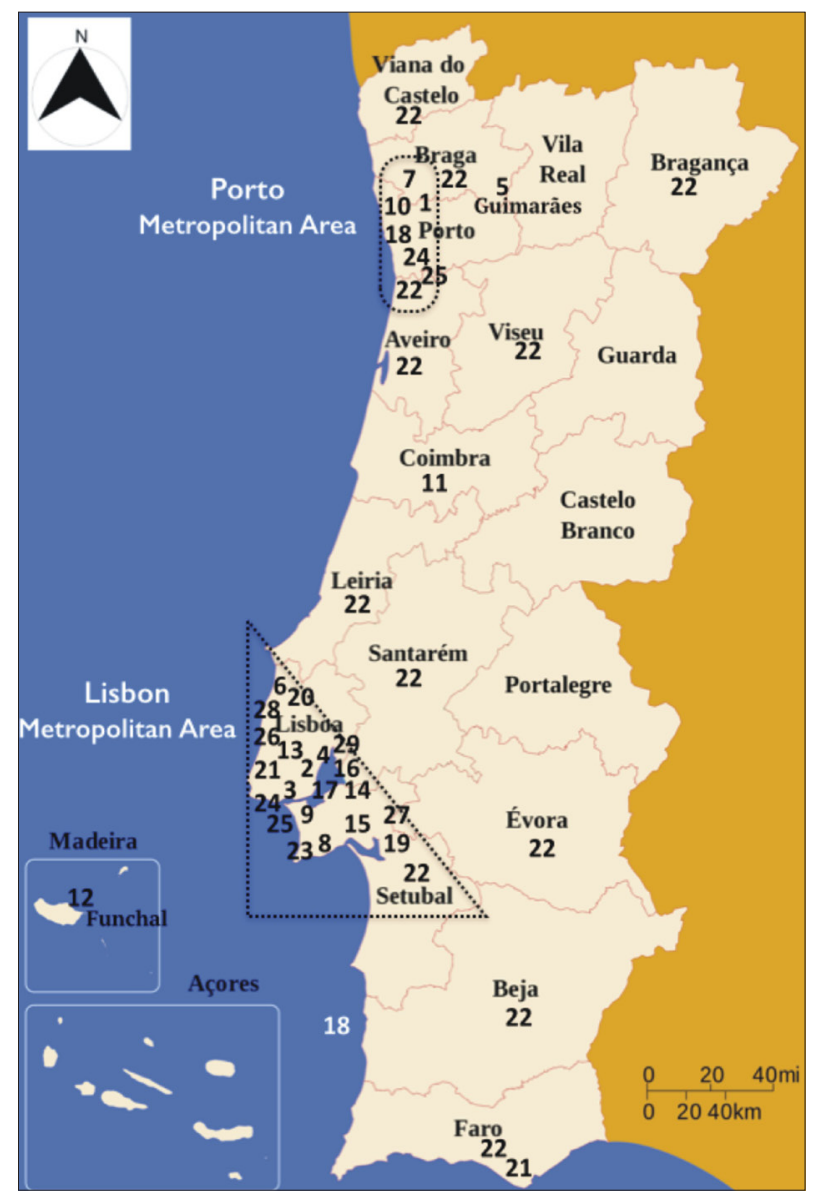

Fig. 1: Location of the 29 UA initiatives in Portugal Legend: (1) Horta à Porta - LIPOR. PMA, (2) Parques Hortícolas de Lisboa, (3) Hortas de Cascais, (4) Horta AVAAL, Lisboa, (5) Hortas de Guimarăes, (6) Hortas Urbanas de V. Franca Xira, 7) Hortas Hospital C. Ferreira, Porto, (8) Parque Hortícola da Quinta da Várzea, Sesimbra, (9) Hortas de S. Joăo, Almada, (10) Hortas de Vila Nova de Gaia, (11) Horta do Ingote, Coimbra, (12) Hortas do Funchal, Madeira, (13) Hortas Cova da Moura, Amadora, (14) Hortas Bairro Boavista, Lisboa (15) Hortas Urbanas da Moita, (16) Horta da Caixa G.D. Lisboa, (17) Projeto Horta Integrada, Lisboa, (18) Hortas da Fundaçăo de Serralves, Porto, (19) Da quinta para o prato, Palmela, (20) Hortas Empresariais, Loures, (21) Horta do Baldio, Lisboa, (22) Programa PROVE, Portugal, (23) Cabaz do Peixe, Sesimbra, 24) Fruta Feia. LMA and PMA, (25) Biovivos,(26) Projeto Semear, Lisboa, (27) Horta Prisăo de Setúbal, (28) Cercica de Cascais, (29) Loja Produtos Rurais, Lisboa Source: author's elaboration (2017)

\subsection{In-depth multi-dimensional analysis}

\subsubsection{Land for urban agriculture}

The results of the analysis of the ownership of land where UA initiatives are taking place reinforces the idea that the majority of UA occurs on public land (14 out of 29 cases) and institutional land (11/29) such as hospitals, foundations, universities or prisons. To a lesser extent UA initiatives are developed on privately-owned or rented land (5/29), mainly by PROVE and Fruta Feia farmers. It is important to note that renting land remains relatively rare as land for UA remains quite expensive in peri-urban areas. Lastly long-term initiatives such as LIPOR (case 1) and Funchal (case 12) take place mainly on public land (Delgado, 2015), but also on private and institutional land, showing that established initiatives are expanding through heterogeneous land ownership regimes.

\subsubsection{Leadership and partnerships}

The data gathered clearly indicate that the public sector and local municipal governments are spearheading the referred initiatives and programmes (14 out of 26 cases). Civil Society Organisations with different thematic foci including ecology, healthy food and permaculture registered in second place $(7 / 26)$, followed by institutions (3/26), private companies (1/26) and informal groups (1/26), such as Horta Integrada (case 17). Programmes and initiatives with clear partnerships and multi-actor processes are still quite limited: four were identified out of the 14 with public leadership and one out of the five spearhead by Civil Society Organisations.

\subsubsection{Asset mapping}

Each initiative was "unpacked" in order to identify their assets, i.e. the number of distribution points, the number of fairs, the number of allotment gardens or the number of peri-urban productive units involved in supplying short food chains. Portuguese UA is quite heterogeneous and covers an extreme diversity of situations which can be summarised as follows:

a. concentration of productive assets in two programmes PROVE with its 170 registered producers and Fruta Feia with its 107 producers, are by far the largest initiatives in the country when considering their productive capacity;

b. multiple-asset initiatives (from 10 to 50) - A second position refers to programmes such as Lisbon Horticultural Parks (case 2) that comprises allotment gardens and other UA-related activities in 25 Parks in the city itself, excluding the metropolitan region. Another emblematic case is Horta a Porta, (case 1) taking place in 8 municipalities of the Porto Metropolitan Region. It is promoted by LIPOR, a waste management public enterprise, and supports the use of compost in 50 allotments located in these 8 municipalities; and

c. A majority of single assets initiatives - the most frequent situation (18 cases out of 29) refers to projects taking place in one municipality only and they are quantified here as "single asset" initiatives. Information on the number of families involved in the case of allotments, or size of land cultivated is still scarce and deserves further research in the future.

\subsubsection{Duration and consolidation through time}

Exploring the trajectories of the 29 referred initiatives through time is extremely fruitful for sketching out and understanding UA in Portugal (see Fig. 2). The first 


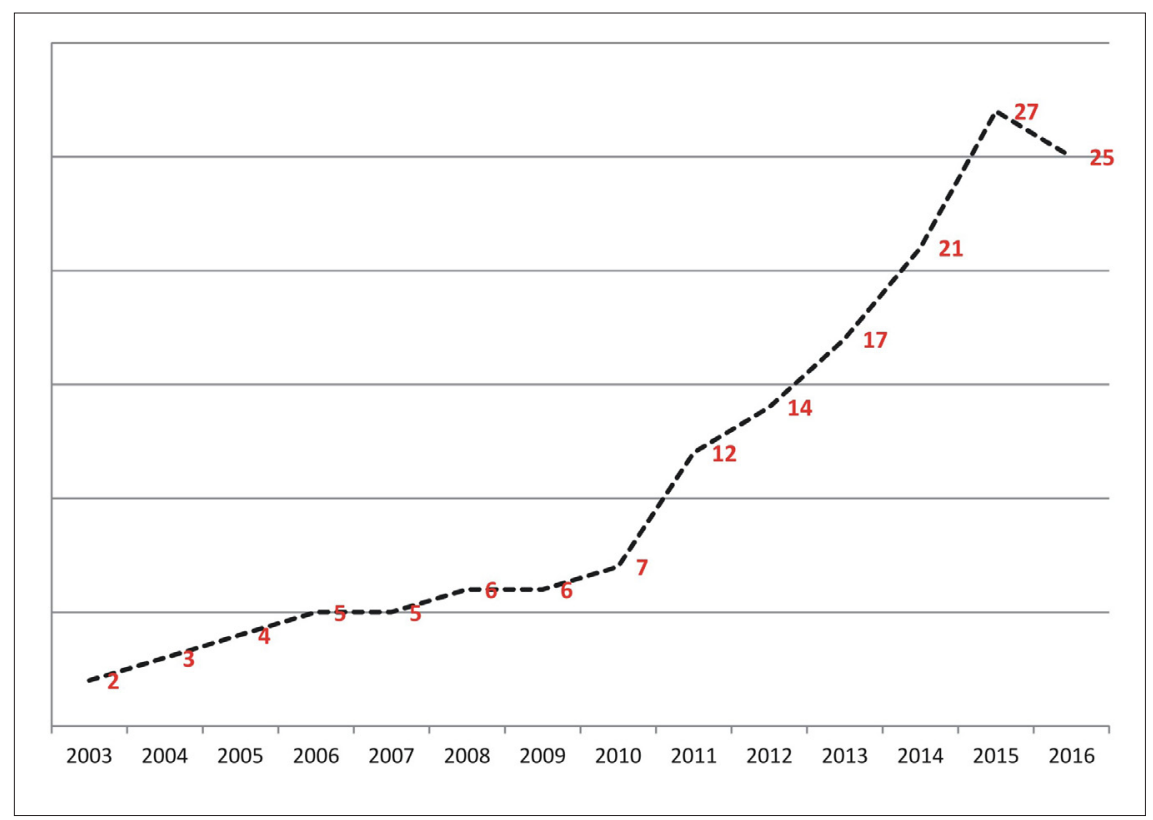

Fig. 2. Evolution of number of UA active initiatives per year

Source: author's elaboration based on information from local actors and key-informants (2017)

observation is that these initiatives have been steadily growing over the past 15 years, since the first one was formalised in 2003. Three periods can be identified and for each the challenges have been quite different.

The three periods are as follows:

a. there was a slow emergence of initiatives before the peak of the 2008 socio-economic crisis (2003-2008) Figure 2 indicates that the number of initiatives steadily grew from two in 2003 to seven in 2008. Most of these initiatives still exist today, in fact many have expanded. They clearly indicate that despite difficulties and lack of supportive policies, they have gained resilience. This is notably the case for emblematic programmes such as LIPOR (2003). Interestingly, some of these pioneering initiatives are not located in Lisbon and Porto. They are found in places that were facing rapid urban expansion but close to rural areas and traditional agricultural initiatives such as Maia in Porto Metropolitan region (case 1), and in Cascais in Lisbon Metropolitan region (case 28) or in secondary cities such as Funchal, capital of Madeira Island (case 12), and in Coimbra (case 11);

b. post-2008 swift expansion of experiments and programmes (2008-2015) - a second period corresponds to quite a remarkable expansion of initiatives of all kinds according to our typology and covers the period stretching from 2008 to 2015 . They resulted, by and large, from the effects of the crisis on Portuguese cities and primarily Lisbon and Porto Metropolitan Regions. In just seven years the number of referred initiatives jumped from 6 to 27. Several of them started their planning process before 2008, a period that was already marked by growing social and economic inequality;

c. slight decrease in the number of initiatives and possible stabilisation (2015- today). The third period mirrors the reduction of the number of initiatives that passed from 27 in 2015 to 25 . The various initiatives that did not continue through time were primarily small-scale, dependent on one champion and that did not survive when the champion disappeared or some local conflict was aroused. This is the case for Horta da Caixa Geral de Depositos in Lisbon (case 16), Programa da Quinta para a Mesa (case 19) and Loja Produtos Rurais (case 29), all of them located in Lisbon Metropolitan Area.

\subsubsection{Activity patterns}

This initiative-based UA profile explains (see Fig. 3) the nature and intensity of activities developed through the 29 initiatives. The activities developed can be organised into three different groups corresponding to what is being carried out day-to-day:

a. Growing Food (22 out of 29 cases) - the first set of activities relates to growing food, either for selfconsumption, as in the case of allotment gardens, or for subsequent distribution (case 22);

b. Food processing and distribution (10/29) - many less initiatives, some projects are integrating food processing and distribution into their practices. One can say without any doubt that UA in Portugal is still essentially a primary industry that deals with unprocessed vegetables and fruit. Packaging, marketing, branding, and publicity are quickly being integrated by various initiatives, however, primarily the social enterprises involved in short circuit food chains;

c. Capacity building, training and support (22 out of 29 cases) - one important finding in this research was the importance of a wide range of activities falling under capacity building, awareness raising, and training in multiple forms (technical, scientific, social, organisational and management). This third group corresponds to 22 of the cases and therefore is of a similar importance to growing food. This particular result is important, as it was very little perceived by the key informants when asked: "How would you define UA in Portugal?" Some of the initiatives focus essentially on training (case 18), but almost all the initiatives with public leadership include mandatory workshops on, for instance, organic production and composting. This is the case for the LIPOR programme, Lisbon Allotments Parks, and Cascais allotments gardens (Abreu, 2012); and 


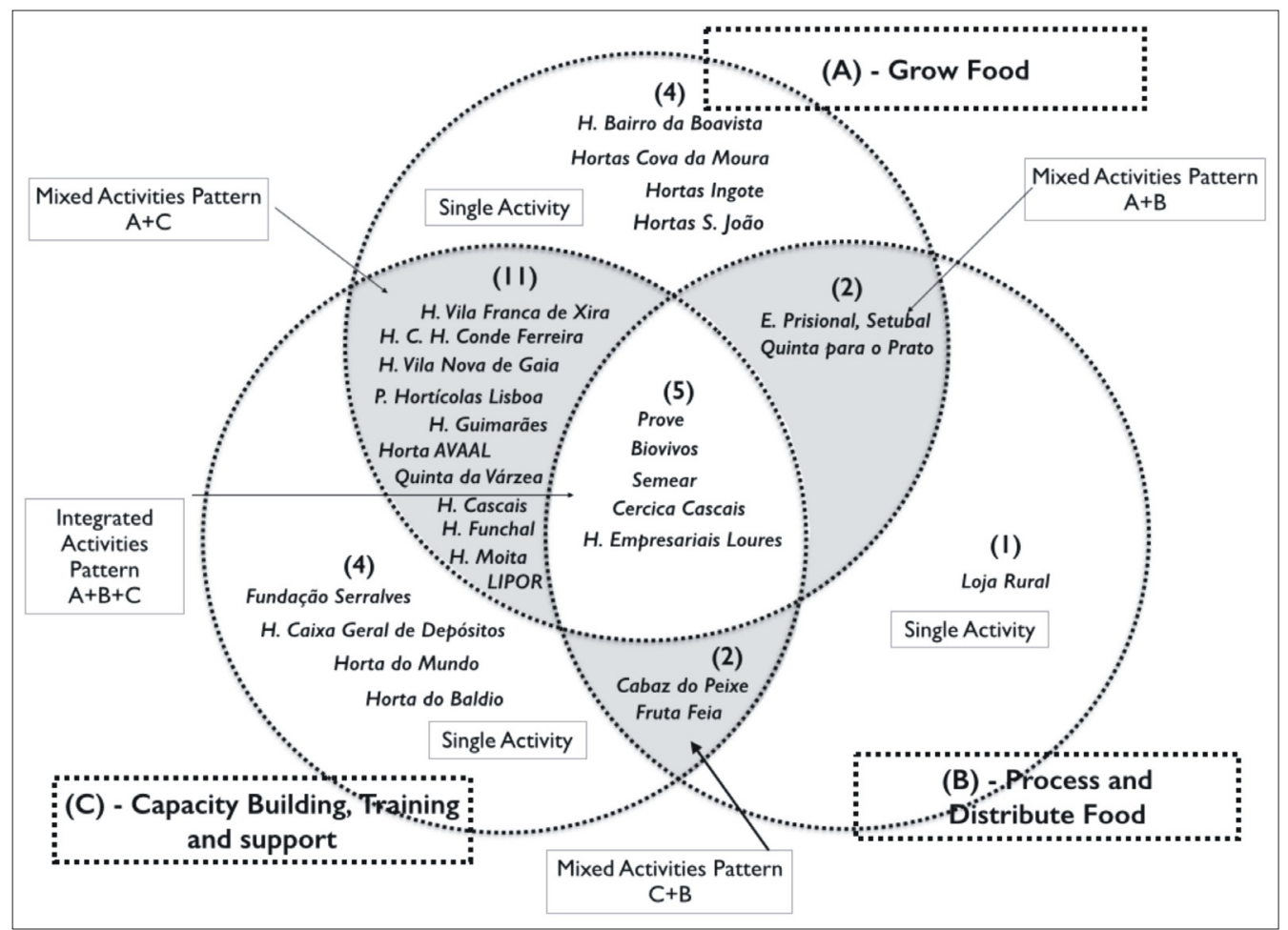

Fig. 3: UA initiatives per activity

Source: author's elaboration (2017)

d. Single, mixed and integrated activities patterns -another finding resulting from the analysis is that three patterns can be identified in UA in Portugal (see Fig. 3). Single activity patterns ( $\mathrm{d}-9$ out 29 ), meaning that the initiative is oriented only towards one activity;

e. Mixed activity patterns (16 out of 29 ), i.e. merging two activities and

f. Integrated activities patterns (5 out 29 ), what means that the initiative is incorporating the three activities, growing food, processing and distributing food plus capacity building, training and support.

\subsection{Creative answers from the social and solidarity economy sector}

This section presents the results of an in-depth exploration into the four short food chains initiatives (Moustier and Renting, 2015) that were identified as an emerging category of UA Typology in Portugal (see Tab. 1). They represent illustrative case-studies as defined by (Flyvbjerg, 2006) of short food chains, targetting urban consumers primarily from Lisbon and Porto Metropolitan Areas. Short food chains initiatives have been emerging in Portugal primarily from young social entrepreneurs (George and Block, 2011) such as Joăo Henriques, today CEOand owner of Biovivos enterprise (Biovivos, 2017), and Isabel Soares, mentor and current CEO of Consumers Cooperative Fruta Feia (Fruta Feia CRL, 2017). Another young woman, Catarina Grilo was the mentor of Cabaz do Peixe, a Community Supported Fish Distribution initiative that is currently run by the local Fishermen's Association (Cabaz do Peixe, 2017). The fourth initiative, PROVE, is promoted by ADREPES, a national association managed by a young team of professionals and activists. Each of these projects is generating new job opportunities (see Tab. 2) in a country recently hit by the crisis where youth employment is a major issue. All together they indicate that some forms of UA, with a strong emphasis on social economy and the environment, have the ability to grow in periods of crisis recovery and to contribute to job creation (Mougeot, 2015). Each one of these four initiatives deserves a closer look, as they are significantly different from the others in the current UA landscape:

- Initiative $1-\mathrm{PROVE}^{1}$ : Creating jobs and bridging the rural-urban divide (case 22)

Since 2006 PROVE has been promoting new forms of short marketing chains between small producers in peri-urban areas and urban consumers. Local action groups, under a national leadership, ADREPES (Maciel, 2016), reinforce the local business capacity of small producers, making full use of the internet to generate sales of fresh local vegetables and fruits. Nowadays, the programme involves 132 producers, half of them female, and 7,000 consumers. It's a win-win situation for producers who obtain a fair price for their work and consumers who conveniently receive fresh produce either at home or in their work places. Currently there are 118 distribution points: 41 in the Lisbon Metropolitan Area, 37 in the Porto Metropolitan Area and an additional 40 spread out primarily in secondary cities throughout the country.

- Initiative 2 - Fruta Feia ${ }^{2}$ : Adding social value and reducing food waste (case 24)

Fruta Feia arose in 2013 from a national project run by Gulbenkian Foundation that aims to support innovative young social entrepreneurs. The cooperative focuses on

\footnotetext{
${ }^{1}$ The project received several awards: European Enterprise Promotion Awards - EEPA (2016); among others

2 The project received several awards: Gulbenkian Foundation (2013); Terre de Femmes (2014); Agriculture Innovation - Bank Foundation (2014); António Sérgio Cooperative - Social Innovation (2014)
} 
challenging market inefficiency by changing consumption patterns and creating an alternative market for fruits and vegetables that are rejected by the suppliers of main food chains and supermarkets. In doing so, they give value to food that would otherwise become waste and bring additional resources essentially to small-scale farmers that have very limited opportunities, if any, to sell fruits and vegetables that are rejected by the dominant corporate distribution system for being too small or of irregular shape. The way Fruta Feia operates is straightforward. Every week two teams work directly with local producers, gathering from their farms big, small, or misshapen products they cannot sell. Even if the cooperative does not have an organic focus, it only works with local farmers whose agricultural practices are environmentally friendly. No more than $70 \mathrm{~km}$ are covered between the farmer and the consumer pickup points which makes it possible to eat vegetables on the same day they were harvested. Once vegetables are collected and brought to distribution points, they are sorted and organised into baskets by a large number of volunteers from the community or other committed citizens. Later in the day they will be picked up by consumers from the vicinity, and it is remarkable to observe that many of them, for instance in downtown Lisbon, are elderly or poor, and suffering from the effects of gentrification and the massive touristification of the country. Most of delivery points in the Lisbon and Porto Metropolitan Areas are predominantly historical buildings belonging to established local organisations. Each delivery point counts approximately 250 consumers and the amount of distributed food from each distribution point means that each week, about 2 tonnes of fresh and nutritious fruit and vegetables were not turned into waste and are consumed.

- Initiative 3 - Cabaz do Peixe ${ }^{3}$ : Between the sea and the city, delivering fish protein and reducing fish waste (case 23)

Cabaz do Peixe started supplying fish in 2015, after almost five years of planning and struggling to create partners' awareness and find new space in existing public policies and practices, and to mobilise financial support, primarily for trucks and facilities. The original idea comes from Catarina
Grilo, mentor of the process and volunteer from the Nature Protection League (Liga para a Proteçăo da Natureza), a relatively small national association. Inspired by similar processes in Canada, Catarina convinced an association of local fishermen that a market-oriented short food chains would bring them an additional source of income.

In 2014, the project received financial support from PROMAR - an EU/Public programme for fisheries, which was implemented in 2015 . The project reduces fish waste, as one third of the basket sold to consumers includes noncommercially valued species and improves environmental sustainability. In additional, another explicit objective is to tighten relations between fishermen and conscious consumers. In roughly one year, the project has attracted more than 300 consumers. Each week, over 100 boxes are delivered to 7 different points: 3 of them in Lisbon, located 45 kilometres away from the fishing port, and the remaining 4 closer to the port itself. The fish is processed in seawater, and then placed in boxes with sea ice, guaranteeing the quality and freshness that distinguishes this product. The Association of Local Ship-owners, a nonprofit organisation, manages the project. So far, two new jobs were created.

- Initiative 4 - Biovivos ${ }^{4}$ : Tiny urban spaces can produce simple, healthy and nutritious food (case 25)

Biovivos was created by Joăo Henriques, a young designer strongly driven by a humanist mission, who spent 12 years working on innovative solutions for Urban Agriculture, primarily rooftop greenhouses in Lisbon's city centre. In 2014 , he started working on a new niche area, focusing on highly nutritious and healthy food. He is now producing three micro-greens: peas, sunflower, and wheat grass in a $32 \mathrm{~m}^{2}$ green house located in Lisbon's Parque Holanda. The micro greens are ready to sell in 1 to 2 weeks, which means a huge turnover. Each week 3,500 green pots are sold mainly to Organic shops and restaurants in Lisbon within a $20 \mathrm{~km}$ radius. Some are distributed by a private company that supplies Porto in the north and Algarve regions in the south. Both regions could become productive centres in the near future. With this undersized greenhouse, the

\begin{tabular}{|c|c|c|c|c|}
\hline & PROVE & Fruta Feia & Biovivos & Cabaz do Peixe \\
\hline Starting date & 2006 & 2013 & 2014 & 2015 \\
\hline Products & Vegetables and fruits & Fruits and vegetables & Microgreens & Fish \\
\hline Production location & Peri-urban & Peri-urban & Urban & Peri-urban \\
\hline Distribution location & Urban and peri-urban & Urban & Urban & Urban \\
\hline Number of consumers & 7,000 & 2,500 & $20+50$ & +300 \\
\hline Distributions points & 118 & 7 & 16 & 7 \\
\hline Sales per week & 7,000 baskets & 2,100 baskets & 800 pots & 100 baskets \\
\hline How distribution is made & Van & Van & Van & Van \\
\hline $\begin{array}{l}\text { Distance (max.) from } \\
\text { production to distribution }\end{array}$ & Up to $50 \mathrm{~km}$ & Up to $80 \mathrm{~km}$ & Up to $20 \mathrm{~km}$ & Up to $50 \mathrm{~km}$ \\
\hline Jobs created full/part-time & $132+$ producers & $8+$ producers & 2 & 2 \\
\hline
\end{tabular}

Tab. 2: Basic comparative data on four Portuguese short circuits' initiatives

Source: Local teams. author's elaboration (2016)

\footnotetext{
3 The project received two awards: Terre de Femmes - Honourable mention (2015) and BPI Agriculture (Bank Foundation Honourable mention (2015).

${ }^{4}$ The project received one award: Portugal Green Award - Honourable mention (2015).
} 
project was able to create two full-time jobs and one parttime job. Joăo wants to expand sales in other cities in order to open new productive centres as close as possible to customers. Soon, he should realise one of his dreams, as a new partnership with Porto University and Porto Oncology Hospital should allow production of micro greens for cancer patients who need them most.

\subsection{Cross-sectional analysis of the four initiatives}

Table 2 highlights the main dimensions of PROVE, Fruta Feia, Biovivos and Cabaz do Peixe. With the exception of PROVE, all them are quite new in the Portuguese UA landscape. Interestingly, PROVE and Fruta Feia give continuity to UA Portuguese mainstream products, vegetables and fruits, whereas Biovivos and Cabaz do Peixe are breaking norms with new products: high-standard healthy food (Biovivos) on the one hand, and fish protein on the other (Cabaz do Peixe), clearly introducing innovation and creativity into the UA Portuguese landscape.

The significant number of producers involved in PROVE and Fruta Feia testify that short food chains are creating jobs and supporting the local economy in peri-urban areas. Fruta Feia and PROVE together are weekly supplying almost 10,000 urban consumers, quite a high number in a country of less than 10 million inhabitants (INE, 2017). This means that they need a constant supply from peri-urban areas in order to satisfy urban consumers' demand. Biovivos and Cabaz do Peixe work with perishable products, as such their territorial scope so far and their consumers markets are comparatively smaller. Nevertheless, Cabaz do Peixe quickly managed to conquer a significant market with 100 fish boxes distributed in Lisbon and Setubal municipalities.

The UA short food chains initiatives described here cannot be isolated from a new culture of social enterprises emerging in Portugal. This is probably a distinctive feature that links all four initiatives and makes them unique. Interestingly, these four food-related initiatives are part of a broader movement of creative industries supported by organisations such as IES, Social Business School founded in 2008 (IES, 2017), CASES - Cooperative António Sérgio for Social Economy (CASES, 2017), or Foundation Padre António Vieira (IPAV, 2017). They work in partnership with several organisations including the Portuguese Government, Municipalities, foundations from the banking sector, Cooperatives, Universities, and other organisations from the social economy sector. By the end of 2016, this huge social economic wave gave rise to a national platform, GEOfundos, which brings together national and international funds to support projects and entities from the social economy sector.

\section{Discussion: How mapping Portuguese UA contributes to the debate}

How significant are UA Portuguese mapping results for the discussion of the previously defined research questions?

Let's go back to our first research question in the UA conceptual definitions debate: Are current UA definitions sufficient to recognise emerging and innovative UA initiatives and to nuance the UA vision of self-consuming production for poverty mitigation? Well, the question should be split into two parts. From one side, our results are confirming that, by and large, the urban agriculture profile as informed by the selected 29 initiatives fits relatively well within conventional definitions proposed by Mougeot (2000) or by RUAF (2006). Some adjustments and comments, however, need to be made to highlight current specificities:

- UA in Portugal is much more about production, i.e. the growing of plants and their distribution and selfconsumption, than business;

- UA in Portugal is still essentially a phenomenon found predominantly in large metropolitan areas with some outreach to the key secondary cities, as such a gap can be identified as an opportunity for expansion and for scaling up that either the current promoters and/or the UA champions could take into consideration;

- UA as a sector is relatively young in Portugal when compared with other countries that are part of the European Federation of Allotments Gardeners. The analysis clearly indicated that all initiatives were less than 15 years old. The explanation comes from Portugal's late urbanisation, among other reasons referred in Section 2. Just as in the northern European countries, however, allotments remain at the core of urban agriculture and are its dominant feature, with municipalities playing a pro-active role;

- The recent expansion of allotment gardens seems to reflect the need to address social exclusion and even hunger as a result of the socio-economic crisis. This is relatively different from northern European countries where most allotment activities are leisure-related (Prové et al., 2016);

- Land rent for UA production (Mougeot, 2015) - or as expressed in the RUAF UA definition: "Competition for land with other urban functions" - is still limited and essentially led by private sector initiatives. This limited competition comes probably from large quantity of urban voids, i.e. available municipal land that can be turned into garden allotments by municipalities, and a still limited size of UA in the country. This shows that UA integration into the city (Mougeot, 2015), has room for improvement;

- The integration of the value chains of UA production is still limited, despite the four innovative short food chains described here. Additionally, the limit today is that the initiatives are still very raw, rooted in unprocessed food products such as vegetables and fruits and do not consider the complete food chain. In consequence, the processing of what is being produced as food and nonfood products, e.g. compost, is still extremely weak;

- Concerning the multiple functions of UA production, the activities patterns analysed are showing an interesting trend on capacity building, training and support. Yet integrative solutions can go much further than this, raising the debate on how UA is perceived by decision makers, a problematic issue, given the top-down decision approach Portuguese system; and

- Physical connectivity of urban agriculture production sites by improving resources utilisation is poor - assets mapping is showing that initiatives are expanding through a replication model based on production (case 1) without a food system approach that considers new resources exploitation. This is clearly a Portuguese challenge that prevents a sustainable development of UA integration.

- These results confirm how problematic it is to define a boundless issue along with the limits of a UA definition concerning the multiple ways UA can be integrated into the city (Mougeot, 2015), and its contribution to 
the urban and social economy. Based on the mapping of Portuguese UA, it is clear how the processing and food distribution activities within UA are neglected in spite of its huge relevance for urban consumers, e.g. Fruta Feia, with more than 2,100 weekly urban consumers, or even Cabaz do Peixe with its 100 basket weekly distribution. It is also obvious that those four innovative short food chains are creating jobs within an economically adverse context, again a forgotten UA output.

Therefore, our first contribution to UA's conceptual debate results from the in-depth multi-level analyses proposed in Section 3. UA conceptual frameworks need to be reformulated in order to gather data that can inform political decisions, as well as be locally specific as city and country background can differ significantly.

Results obtained so far also help to clarify the theoretical debate introduced earlier: To what extent is collaborative planning theory adequate to understand and facilitate the development of UA programmes? First, the multiple origins of UA leaderships are quite positive even if these actors established very few working connections between themselves. Second, the lack of communication among municipalities and citizens, civil society and organisations is the biggest challenge UA has to address in order to scale-up in future. Furthermore, this is a key point for understanding present difficulties of a systemic approach to UA, either in cities or at the national level. Portugal's lack of networking skills as mentioned by Franco (2015) and unbalanced stakeholders power can not guarantee that a Collaborative Planning approach will succeed, at least in a short- or medium-term scenario. This is a topic that calls for more in-depth research. Third, this looseness of relations might explain the limited lobbying capacity of the sector and its limited impact on more supportive public policies. It might explain as well the lack of integration within the European federation of Allotments Gardeners. This is one challenge for the future development of UA in Portugal and certainly a difference with growing trends in other European countries.

Lastly, our third research question: How crisis-induced initiatives can be a starting point and an opportunity to integrate UA into the city in the long-term? Again two different streams can be perceived from mapping out UA Portuguese initiatives.

On the one hand, the recent reduction of initiatives can be explained by some positive signs of economic recovery, which are now being felt and have released the pressure on food needs. Further research on this issue could be one of the tasks carried out by a strongly-needed national research programme on UA that does not exist at the moment. These observations certainly raise the issue of how to avoid volatility but one of our conclusions so far is that very few projects closed down and most of them have shown a remarkable level of resilience, which is quite promising. Potential lessons can be drawn from here and serve for both the expansion of the sector in Portugal and beyond. They do raise, however, a more fundamental theoretical and practical issue on how to shift from crisis-induced urban agriculture to a permanent social and economic activity within a sustainable development approach.

On the other hand, our results also show a post-crisis emergence of creative urban agriculture and food initiatives that are little known and that are potential avenues to feed cities differently in Portugal and beyond. By and large they are part of the digital era and rely for most of their activities on social networks to keep consumers informed and events spread out and on ICT-using consumers platform applications (PROVE, Fruta Feia and Cabaz do Peixe). All these innovative processes are heavily supported by social networks, which give them national and in some cases international recognition and exposure. They are collectively breaking the paradigm of vertical, top-down decision making, that is common in Portugal. They are different from most emerging creative industries as they have quite a strong social and environment commitment, grounded in fair prices for producers and consumers; food waste reduction (Fruta Feia); healthy food at fair price (Biovivos); market opportunities for undervalued commercial species (Cabaz do Peixe) and job creation in peri-urban areas (PROVE). Although they represent a niche (Geels, 2011), what is remarkable and interesting from a research and theoretical perspective is that such initiatives are paving the way for UA to shift from an answer to the effects of the crisis in Southern European countries, towards a fully-fledged sector for a sustainable and just local development, making creative use of social networks and ICTs, already highlighted in the early 1990s by Jac Smith (Levenston, 2010). In summary such initiatives can contribute to establish positive bridges to research and exchange on how public policies could contribute to building better and longer-term food systems in Europe.

\section{Concluding remarks and policy implications}

The 29 UA initiatives analysed corroborate Portugal's vibrant UA landscape. In particular they highlight the relevance of innovative short food chains for shifting from UA as an immediate response to crisis to a more integrated UA with a long-term perspective, for at least three reasons:

a. they demonstrate the positive role of ICT and the Internet on UA growing popularity and expansion;

b. some of them might lead the way to a positive UA future scenario. Blooming bottom-up initiatives, even if still limited in scale, could expand while keeping their strong social and environmental commitment. Their scaling-up and sustainability, however, will largely rely on public policies; and

c. they are consistent examples that market-oriented UA solutions, even without the support of public policies, can emerge and generate jobs in time of crisis, as in other European countries, regions and cities, primarily from southern European countries.

In contrast, we consider that long-term sustainable development cannot be carried out without public policy and political commitment. Results are showing the lack of communication between actors and to a certain extent even amongst municipalities and Civil Society Organisations. Why is this important? Firstly, it confirms the urgency of additional democratic approaches in order to develop UA food policies, which goes back to our theoretical background. Secondly, this confirms the need to have a political debate about UA in order to re-frame understandings of UA amongst all the stakeholders involved. In conclusion, the change from UA as a response to the effects of the crisis towards long-term, local development must be done with a clear vision of UA, within a democratic process that involves all stakeholders.

Is collaborative planning theory able to make the bridge between diverse and unbalanced stakeholders involved in the processes, and a long-term transformative change in 
countries where participation is not commonly practised? This topic is critical, as developing UA policies requires political commitment, involving all stakeholders, as well as interdepartmental coordination and financial budgeting. Grounded in evidence we must say no - at this point in time, given the lack of democratic approaches in southern European countries, collaborative planning is not yet the answer. Here we stand, looking for an alternative paradigm that can respond to the challenge of connecting public power with local initiatives to create long-term integration of UA into the city. The question is still unanswered. More research must be done. New approaches such as an integrative management framework that considers UA's holistic potential for social development and economic growth, could be the foundation for establishing long-term local development solutions, based on the community's empowerment.

In the meantime, to reach this turning point and scale up, there is an urgent need to pursue research and to set up a National Urban Agriculture Observatory that would identify, map out and permanently assess UA mainstream initiatives, as well as innovative ones that are emerging from the social economy sector. This accumulated knowledge, and positive examples, could fuel urban planning policies at the European, national and local levels, and largely legitimise emergent UA initiatives that are today underrated and little known, not only in Portugal, but also across Europe. This means that proper public policies and master plans are needed. They are, in fact, a priority in order to consolidate and scale up urban agriculture in countries, regions and cities.

\section{Acknowledgment}

The research is funded by the Portuguese Science and Technology Foundation (FCT) grant: SFRH/ BPD/94286/2013. The author acknowledges the unique contribution of all informants and expresses her gratitude to each individual who has made this work possible, and to Christopher Yap for his contribution to the present version.

\section{References}

ABREU, A. (2012): Hortas Urbanas - Contributo para a sustentabilidade: Caso de Estudo: "Hortas Comunitárias de Cascais". Faculdade de Cięncias e Tecnologia da Universidade Nova de Lisboa.

ALMEIDA, T. (2012): Horticultura Social no Estabelecimento Regional de Setubal. Revista da Associaçăo Portuguesa de Horticultura, 110: 39-42.

AMERICAN PLANNING ASSOCIATION (2007): Policy Guide on Community and Regional Food Planning. American Planning Association: American Planning Association.

ATKINSON, R., FLINT, J. (2001): Accessing Hidden and Hard-to-Reach Populations: Snowball Research Strategies. Social research UPDATE, Department of Sociology University of Surrey.

BELL, S., FOX-KÄMPER, R., KESHAVARZ, N., BENSON, M., BENSON, M., NOORI, S., VOIGT, A. [eds.] (2016): Urban Allotment Gardens in Europe.

BIERNACKI, P., WALDORF, D. (1981): Snowball Sampling Problems and Techniques of Chain Referral Sampling. Sociological, Methods \& Research, 10: 141-163.
BIOVIVOS (2017): Biovivos I Facebook [online]. [cit. 04.2017]. Available at: https://www.facebook.com/biovivos/

BRANCO, C. (2016): Relatório Nacional I Habitat III. [cit. 01. 2017]. Available at: http://habitatiii.dgterritorio.pt/ sites/default/files/ficheiros publicos/PT_UN-HabitatIII NationalReport_2016_08_04_EN.pdf: Direçăo Geral do Território

BRYANT, C., DIAZ, J. P., KERAITA, B., LOHRBERG, F., YOKOHARI, M. (2016): Urban Agriculture for a global Perspective. In: Lohrberg, F., Licka, L., Scazzosi, L., Timpe, A. [eds.]: Urban Agriculture Europe. Berlin, JOVIS Verlag GmbH.

CABANNES, Y., MAROCCHINO, C. (2016): Integating Food Security onto urban planning. In: Cabannes, Y., Marocchino, C. [eds.]: Envisioning Future Cities - Ideas and Examples. ISOCARP.

CABANNES, Y., RAPOSO, I. (2013): Peri-urban agriculture, social inclusion of migrant population and Right to the City. City: analysis of urban trends, culture, theory, policy, action, 17(2): 235-250.

CABAZ DO PEIXE (2017): Cabaz do Peixe [online]. [cit. 04. 2017]. Available at: http://www.cabazdopeixe.pt

CANCELA, J. (2014): A agricultura urbana na operacionalizaçăo da estrutura ecológica municipal. O estudo de caso do Parque Agricola da Alta de Lisboa. Tese de Doutoramento. Faculdade de Arquitectura da Universidade de Lisboa.

CARDOSO, S. (2012): Arquitectura e o espaço agrícola. Sustentabilidade participada: um projecto para o Vale de Carnide. Tese de Mestrado. Faculdade de Arquitetura da Universidade de Lisboa.

CASAQUI, V. (2015): Ideias Portuguesas para mudar o mundo: Projetos de empreendimentos sociais, cultura e espírito do tempo. O empreendedorismo Social e a Economia Solidária. Portugal: ACEESA - Associaçăo Centro de Estudos de Economia Solidária do Atlântico, Portugal.

CASES (2017): CASES - Cooperativa António Sérgio pra a Economia Social [online]. [cit. 01. 2017]. Available at: http://www.cases.pt

CMF (2015): Hortas Urbanas (do Funchal) [online]. [cit. 04. 2017]. Available at: http://www.cmfunchal.pt/ambiente/index.php?option $=$ com content\&view $=$ article\&id $=189 \&$ Itemid $=272: \quad$ Câmara Municipal do Funchal

CML (2016): Sítio da Câmara Municipal de Lisboa: Parques Hortícolas Muniícipais [online]. [cit. 04. 2017]. Available at: http://www.cm-lisboa.pt/viver/ambiente/parqueshorticolas-municipais: Câmara Municipal de Lisboa

COIN DE TERRE ET DES JARDINS FAMILIAUX (2014): European Allotments Federation - Information Brochure. In: Office International du Coin de Terre et des Jardins Familiaux.

CROUCH, D., WARD, C. (2007): The allotment Its Landscape and Culture, Nottingham, Great Britain, Five Leaves Publ.

CRUZ, C., AGUILA, R. (2000): Conceptual Framework for Urban Agriculture. Trialog 65. A Journal for Planning and Building in the Third World, 2: 4-8.

DELGADO, C. (2015): Answer to the Portuguese Crisis: Turning Vacant Land into Urban Agriculture. Cities and the Environment, 8: 20. 
DELGADO, C. (2016): Agricultura Urbana em Portugal: un setor de futuro em expansăo. Revista da Associaçăo Portuguesa de Horticultura, 121: 14-17.

FAINSTEIN, S. (2000): New directions in planning theory. Urban Affairs Review, 35: 451-478.

FAO (2009): Food, agriculture and cities: challenges and priorities.

FAO (2017): FAOSTAT. Available at: http://www.fao.org/ faostat/en/\# country/174

FERRAZ, J. (1975): O desenvolvimento socioeconómico durante a Primeira República (1910-26). Análise Social, XI: 42-43.

FLYVBJERG, B. (2006): Five Misunderstandings About Case-Study Research. Qualitative Inquiry 12: 219-245.

FRANCO, R. C [ed.] (2015): Diagnóstico das ONG em Portugal. Lisboa, Fundaçăo Calouste Gulbenkian [online]. Available from: https://gulbenkian.pt/wp-content/uploads/2017/01/ PCA_DiagnosticoONGPortugal2015.pdf

FRUTA FEIA CRL (2017): Fruta Feia I Gente Bonita Come Fruta Feia [online]. [cit. 04. 2017]. Available at: http:// www.frutafeia.pt/en

GEELS, F. (2011): The multi-level perspective on sustainability transitions: Responses to seven criticisms. Environmental Innovation and Societal Transitions, 1: 24-40.

GEORGE, G., BLOCK, A. (2011): The business model in practice and its implications for entrepreneurship research. Entrepreneurship Theory and Practice, 35: 83-11.

GONÇALVES, R. (2014): Hortas Urbanas: Estudo de Caso de Lisboa. (Doctoral dissertation, ISA).

GOODSPEED, R. (2016): The Death and Life of Collaborative Planning Theory. Urban Planning, 1: 1-5.

HEALEY, P. (2004): Creativity and Urban Governance. Police Studies, 25(2): 11-20.

HEALEY, P. (2006): Collaborative Planning: Shapping Places in Fragmented Societies (2 ed.), Palgrave.

HUXLEY, M., YIFTACHEL, O. (2000): New paradigm or old myopia? Unsettling the communicative turn in planning theory. Journal of Planning Education and reseach, 19: $333-342$.

IES (2017): IES - Social Business School [online]. [cit. 01.2017]. Available at: http://ies-sbs.org/\#intro

INE (2017): Populaçăo residente em Portugal [online]. Instituto Nacional de Estatística. Available: https://www. ine.pt/xportal/xmain?xpgid=ine_main\&xpid=INE

INE-CASES (2013): Conta satelite da Economia social. Lisboa.

INNES, J. E., BOOHER, D. (1999): Consensus Building and Complex Adaptive Systems: A Framework for Evaluating Collaborative Planning. Journal of the American Planning Association, 65: 412-423.

INNES, J. E., BOOHER, D. E. (2010): Planning with Complexity: An Introduction to Collaborative Rationality for Public Policy, Routledge.

IPAV (2017): IPAV - Instituto Padre António Vieira [online]. [cit. 01. 2017]. Available at: http://www.ipav.pt

LANÇA, S. (2011): Congresso internacional agricultura urbana e sustentabilidade - Conteudos para a promoçăo do encontro. In: Seixal, C. M. D. [ed.]: Congresso internacional agricultura urbana e sustentabilidade. Seixal - Portugal. Câmara Municipal do Seixal, 242.
LEVENSTON, M. (2010): The internet and urban agriculture. Journal of Ahriculture, Food Systems, and Community Development, 1: 28-29.

LIPOR (2017): Horta à Porta - Lipor [online]. [cit. 04.2017]. Available at: http://www.lipor.pt/en/ environmental-awareness/horta-da-formiga/organicfarming/horta-a-porta/

LOHRBERG, F., LICKA, L., SCAZZOSI, L., TIMPE, A. (2016): Urban Agriculture Europe, JOVIS.

LUIZ, J. T., JORGE, S. (2011): Hortas urbanas cultivadas por populaçőes cabo - verdianas na Área Metropolitana de Lisboa: entre a produçăo de alimentos e as sociabilidades no espaço urbano năo legal. Miradas en Movimiento, MeM Special Volume, Naturally Immigrants.

MACIEL, C. (2016): Solidarity Economy in Portugal: Good Practice Example: ADREPES. Lisboa, Instituto Marquęs de Valle Flôr [online]. Available at: https://issuu.com/ imvf/docs/adrepes_en

MORGAN, K. (2014): Nourishing the city: The rise of the urban food question in the Global North. Urban Studies Journal Limited, 1: 1-16.

MOUGEOT, L. J. (2000): Urban agriculture: Definition, presence, potential and risks. Ottawa, International Development Research Centre.

MOUGEOT, L. (2005): AGROPOLIS The Social, Political and Environmental Dimensions of Urban Agriculture. Earthscan and the International Development Research Centre.

MOUGEOT, L. (2015): Urban Agriculture in Cities of the Global South: Four Logics of Integration. In: Imbert, D. [ed.]: Food and the City: Histories of Culture and Cultivation (pp. 163-193). Harvard University Press.

MOUSTIER, P., RENTING, H. (2015): Urban Agriculture and short chain food marketing in developing countries. In: de Zeeuw, H., Drechsel, P. [eds.]: Cities and Agriculture: Developing resilient urban food systems (pp. 121-138).

MUFPP (2015): Milan Urban Food Policy Pact [online]. [cit. 04.2017]. Available at: http://www. milanurbanfoodpolicypact.org/text/

OIKOS (2017): OIKOS - Apelo Pacto de Milăo sobre Política de Alimentaçăo Urbana [online]. Available at: http:// www.oikos.pt/pt/participe/envolva-se-em-campanhas-demobilizacao/item/2119-apelo-pacto-de-milăo

PASCUAL, J. E. (2015): Empresas, Emprendedurismo Y Empresariado Social. O empreendedorismo social e a economia solidária, 18-49.

POTHUKUCHI, K., KAUFMAN, J. L. (1999): Placing the Food System on the Urban Agenda: The Role of Municipal Institutions in Food Systems Planning. Agriculture and Human Values, 16: 213-224.

PROVE (2017): PROVE - Promover e vender [online]. [cit. 04.2017]. Available at: http://www.prove.com.pt/ www/english.T9.php

PROVÉ, C., DESSEIN, J., KROM, M. D. (2016): Taking context into account in urban agriculture governance: Case studies of Warsaw (Poland) and Ghent (Belgium). Land Use Policy, 56: 16-26.

QUINTÃO, C., PARENTE, C. (2015): As escolas do pensamento sobre o empreendedorismo social. O empreendedorismo social e a economia solidária, 50-81. 
RAJA, S., HOEKSTRA, F., DELGADO, C., VEENHUZIAN, R. V. (2016): Community Involvemnet in Urban Planning and Policy Development to Strengthen Regional Food Systems. UA Magazine - Inclusive Use of Urban Space, 31: 51.

RAMOS, A. (2011): A integração de espaços de cultivo agricola em contextos urbanos, Vale de Chelas, Dissertação para a obtenção do grau em mestre em arquitectura, IST, Lisboa.

RAUSCHER, R.C., MOMTAZ, S. (2015): Sustainable Neighbourhoods in Australia: City of Sydney Urban Planning. New York/Dordrecht/London, Springer.

RODRIGUES, S. C. (2012): Um modelo para a implementaçăo de redes de hortas urbanas. Master Thesis. Viana do Castelo, Instituto Politécnico de Viana do Castelo [online]. Available at: http://repositorio.ipvc. pt/bitstream/20.500.11960/1124/1/Susana_Rodrigues.pdf

RUAF (2006): Urban agriculture: what and why? [online] [cit. 03. 02. 2015]. RUAF Foundation Web Page. Available at: http://www.ruaf.org/urban-agriculturewhat-and-why

SANTOS, F. (2011): Hortas Urbanas de iniciativa comunitária - Participaçăo e Desenvolvimento: dois casos de estudo. Tese de Mestrado. Instituto Universitário de Lisboa - ISCTE.

SARAIVA, R. A. (2011): As Hortas Urbanas na reconfiguraçăo física, social e ambiental doConcelho de Oeiras. Tese de
Mestrado. Universidade Nova - Faculdade de Cięncias Sociais e Humanas da Universidade Nova de Lisboa.

SCHAAP, L., GEURTZ, C., GRAAF, L. D.,KASTEN, N. (2009): Innovations in sub-national government in Europe: A quick scan. Tilburg School of Politics and Public Administration Tilburg University, The Netherlands.

SIMON-ROJO, M., RECASENS, X., CALLAU, S., DUZI, B., EITHER, S., HERNANDEZ-JIMENES, V., KETTLE, P., LAVISCIO, R., LOHRBERG, F., PICKARD, D., SCAZZOSI, L., VEJRE, H. (2016): From Urban Food Gardening to Urban Farming. Urban Agriculture Europe.

TEIXEIRA, M. (1993): A história urbana em Portugal. Desenvolvimentos recentes. Análise Social, XXVIII: 371-390.

VEENHUIZEN, R. V. (2006): Introduction, Cities Farming for the Future. Cities Farming for the Future, Urban Agriculture fr Green and Productive Cities. RUAF Foundation; IIRR; IDRC.

VEJRE, H., SIMON-ROJO, M. (2016): Phenomenon: Introduction. In: Lohrberg, F., Licka, L., Scazzosi, L., Timpe, A. [eds.]: Urban Agriculture Europe (pp. 16-17). Berlin, Jovis.

WASCHER, D., KNEAFSEY, M., PINTAR, M., PIORR, A. (2015): Food Metres: Food Planning and Innovation for Sustenaible Metropolitan Regions - Synthesis Report.

ZEEUW, H. D., DRECHSEL, P. (2015): Cities and Agriculture: Developing resiliente urban food systems. Routledge.

\section{Please cite this article as:}

DELGADO, C. (2017): Mapping urban agriculture in Portugal: Lessons from practice and their relevance for European post-crisis contexts. Moravian Geographical Reports, 25(3): 139-153. Doi: 10.1515/mgr-2017-0013. 